\title{
Lexicography and Encyclopaedistics in the Digital Environment
}

\author{
Nataša Jermen, Cvijeta Kraus, Irina Starčević Stančić \\ The Miroslav Krleža Institute of Lexicography \\ Frankopanska 26, Zagreb, Croatia \\ natasa.jermen@lzmk.hr, cvijeta.kraus@lzmk.hr, irinas@lzmk.hr
}

\section{Summary}

This paper presents the current as well as the planned future activities concerning the transformation of the Miroslav Krleža Institute of Lexicography into an e-institution. The authors outline the transformation process of the lexicography and encyclopaedistics from a traditional to a digital environment. The activities concerning the establishment of the publicly available repository of encyclopaedic knowledge are discussed. Furthermore, methods of digital communication with users are described, namely web pages and social media channels, in the context of the Institute's activities. The authors acknowledge that publishing of encyclopaedic editions faces challenges and changes in the digital environment. Digital technologies are transforming the encyclopaedic profession and ways of preparing and presenting encyclopaedic knowledge. The authors explain the changes that should be made in order to drive the Miroslav Krleža Institute of Lexicography towards becoming a fully blown e-institution.

Keywords: The Miroslav Krleža Institute of Lexicography, e-institution, lexicography, encyclopaedistics, digital environment, repository of encyclopaedic content, social media networks

\section{Introduction}

The Miroslav Krleža Institute of Lexicography is a public institution of special status for the Republic of Croatia. ${ }^{1}$ It is the only Croatian institution that has been systematically engaged in lexicography and encyclopaedistics ${ }^{2}$ since its foundation in 1950. As a publishing house, as well as a scientific institution, the Institute over the course of its 65-year history has published more than 250 dif-

\footnotetext{
${ }^{1}$ The Law on the Miroslav Krleža Institute of Lexicography (in Croatian), Official Gazette 96/03, 190/03.

${ }^{2}$ In Croatia, Lexicography and encyclopaedistics is a branch in the scientific field Information and communication sciences. Lexicography is engaged in systematic compiling of the words and their forms, according to certain rules and criteria which are then published in dictionaries, lexicons and encyclopaedias. Encyclopaedistics is a scientific discipline which is engaged in principles and practises of assembling encyclopaedias.
} 
ferent encyclopaedias, dictionaries, lexicons and other editions that represent an important contribution to continuation and advancement of the Croatian intellectual standard.

The main role of the Institute is based on the activity of lexicography and encyclopaedistics which through systematising, synthesising, indexing, storing and distributing information gives the opportunity for a reliable access to global knowledge and enables a systemic orientation within the ever-increasing amount of data and information. ${ }^{3}$ Furthermore, the role of the Institute is to research and understand Croatia's natural and historic heritage, as well as to preserve its cultural and social identity. The Institute's potential lies in the huge resources of created and stored knowledge, which are continuously being digitised and as such it is becoming accessible to a large number of users via the Institute's web pages. At present, the Portal of Knowledge offers free access to more than 60,000 articles from seven digitised encyclopaedias and lexicons ${ }^{4}$. Also, online and freely available editions currently are Croatian Encyclopaedia and Proleksis Encyclopaedia - the two general encyclopaedias that emphasise contents regarding Croatian national heritage, which together comprise of more than 120,000 articles. They are continuously updated and expanded ${ }^{5}$. Apart from the encyclopaedic content, the web pages of the Institute offer access to the digitised Author Catalogue ${ }^{6}$ of the Catalogue of Retrospective Bibliography of the Articles which in total is comprised of 10 million leaflets containing lists of articles from periodicals published in the South-Slavonic area in the period from the end of the 18th century until the year 1945. Open access to the Institute's peer-reviewed scientific journal Studia lexicographica (launched in 2007) is also available. ${ }^{7}$ By enabling the open access to the online encyclopaedic and scientific content, the Institute supports the open science initiative ${ }^{8}$ and contributes to the dissemination of public knowledge in Croatia.

Certain aspects of the future development of the Institute as an e-institution have been recognised and incorporated in the Institute's vision statement. ${ }^{9}$ One of the main goals of the Institute's activity in the years to come will be to up-

\footnotetext{
${ }^{3}$ Strategy of the Miroslav Krleža Institute of Lexicography 2015-2020 (in Croatian).

${ }^{4}$ Portal of Knowledge, http://enciklopedija.lzmk.hr (14.06.2015).

${ }^{5}$ Croatian Encyclopaedia, http://enciklopedija.hr; Proleksis Encyclopaedia, http://proleksis.lzmk. hr (14.06.2015).

${ }^{6}$ The Digitised Author Catalogue, http://katalog.lzmk.hr (14.06.2015).

${ }^{7}$ Studia lexicographica, http://www.lzmk.hr/hr/leksikografska-djelatnost/studia-lexicographica (14.06.2015).

${ }^{8}$ Digital Agenda for Europe - A Europe 2020 Initiative, http://ec.europa.eu/digital-agenda/en/ open-science (14.06.2015).

${ }^{9}$ Strategy of the Miroslav Krleža Institute of Lexicography 2015-2020 (in Croatian).
} 
grade its encyclopaedic online systems with the intention to develop public knowledge of a highest scientific relevance, as well as to create an integral, publicly available digital repository of encyclopaedic content.

This paper aims to give an insight into the current as well as planned activities of the Miroslav Krleža Institute of Lexicography concerning upgrade of the lexicographic and encyclopaedic system in the context of information and communication technologies (ICT). The challenge is how to utilise this technology successfully, and develop the Institute as an e-institution. The transformation process of the encyclopaedic profession from the traditional, i.e. paperbased environment to the digital environment, as well as the process of development of the repository of digitised and online encyclopaedic content will be shown. Moreover, the necessity of the interaction with users of the Institute's online content through the new methods of communication, such as social networks, is pointed out.

\section{Towards an e-institution - basic concepts in the digital environment}

The increase of ICT's influence has affected all spheres of human life and activities. This influence is highly felt in the institutional and business environment too. The spread of ICT's influence has challenged encyclopaedia publishers and brought changes to the institutions publishing encyclopaedias and lexicons, which nowadays are dominantly in the digital form. Although each institution is unique, any institution can be viewed as dynamic, open, efficient and undeterminable social system acting in an environment or at a market and has the task of achieving its goal, i.e. to transform inputs or resources to outputs, products or services intended for the users. ${ }^{10}$

When an institution is functioning in the digital environment and is developing a digital product distributable over the network, ICT is one of the foundation of its business processes. All information and data are in a digital form and usually stored in databases. Generally speaking, an e-institution should be looked upon as a complex business and information system consisting of five components: (1) hardware, (2) software, (3) orgware, (4) lifeware, and (5) e-content. In this context hardware consists of computers, network devices and other devices for data processing and transmission. Software consists of programs for conducting everyday business. Orgware consists of regulations and procedures aiming at keep the system functioning as a harmonious unit. Lifeware is referring to the employees, and e-content is the digital content that can be transmitted over a computer network such as the internet ${ }^{11}$. E-content could be any form of data such as text, graphic, picture, sound, video, animation or 3D object that can be stored in a database and be searched and retrieved.

\footnotetext{
${ }^{10}$ Ekonomski leksikon / ur. Z. Baletić. Zagreb, Leksikografski zavod Miroslav Krleža i Masmedia, 1995, 627.

${ }^{11} \mathrm{PC}$ encyclopaedia, http://www.pcmag.com/encyclopedia/term/42225/e-content (14.06.2015).
} 
Certain necessary preconditions need be satisfied in order for an institution to be considered as an e-institution. From the technological point of view, it is necessary that the ICT infrastructure has been implemented and is operational. From the business standpoint, new business model processes with accompanying standards, routines and procedures should be developed. Having the ICT infrastructure in itself is not enough. The new business model should enable full utilisation of ICT.

The transition of the Miroslav Krleža Institute of Lexicography to an e-institution will not happen overnight. The process will be a slow and complex, entailing installation and utilisation of the ICT equipment, introduction of the improved business model in the context of encyclopaedic profession, involvement of employees proficient with the concept of lexicography and encyclopaedistics in the digital environment, upgrade of the Institute's e-content and finally development of programs for conducting everyday business, such as content management systems (CMS), document management systems (DMS), records management systems (RMS) with the necessary rules and procedures for data management and preservation. A wider institution-level system, combining the mentioned systems, is called Enterprise Content Management System (ECMS). It denotes the strategies, methods and tools used to capture, manage, store, preserve, and deliver content and documents related to institutional processes. ${ }^{12}$

Since institutions are dynamic systems that depend on the surrounding environment, changes in the environment in return influence institutional functions. Therefore, it is necessary that the Institute adapts the interaction with the users of its e-content, i.e. its environment, and develops an active social media presence.

\section{Lexicographic work in the digital environment}

The basic activity of the Miroslav Krleža Institute of Lexicography is lexicography and encyclopaedistics. This consists of the acquisition, processing and verification of data that, accompanied by fundamental scientific research in order to apply common lexicographic and encyclopaedic standards, are stored in a database and used for the creation and publishing of various printed or online editions. ${ }^{13}$ Those editions offer scientifically verified information in a number of fields of human knowledge and contribute to the systematisation and public presentation of specific scientific disciplines, social and cultural phenomena.

Lexicographic work, which is carried out by lexicographers, is defined as the "performance of professional and scientific activities in the field of lexicogra-

\footnotetext{
${ }^{12}$ What is Enterprise Content Management (ECM)?, Association for Information and Image Management (AIIM), http://www.aiim.org/What-is-ECM-Enterprise-Content-Management (14.06.2015).

${ }^{13}$ The Law on the Miroslav Krleža Institute of Lexicography (in Croatian), Official Gazette 96/03, 190/03; Statute of the Miroslav Krleža Institute of Lexicography (in Croatian), Official Gazette 66/2013.
} 
phy and encyclopaedistics". ${ }^{14}$ There is a wide range of activities included in the process of lexicographic work, starting from the acquisition of data to the final step of their incorporation into the editions. The framework of lexicographic work is the composition (writing) of lexicographic and encyclopaedic units and the adjustment (editing) of those units to lexicographic and encyclopaedic as well as scientific standards. In addition lexicographic work consists of language, art, bibliographic and cartographic editing as well as creation of the web applications as the basis for the performance of lexicographic work.

There has been a step change from the traditional concept of lexicography and encyclopaedistics following the introduction of the ICT into the Institute's business process. Since the late 1990s the appropriate steps have been taken to transform the process of lexicographic work from the traditional (i.e. paperbased) to the digital environment. During this time, a computerised editorial system was created in order to support publishing of the paper-based Croatian Encyclopaedia. As only administrators had the full access to the system, all lexicographic processes were still done in the traditional way. In 2007 the Institute started developing web applications to support several printed editions. The first step of the Institute towards offering online editions was in 2009 when the Portal of Knowledge was made available online. ${ }^{15}$

At present, in common to many contemporary publishing houses, the working process on the majority of Institute's projects is now performed in the digital environment, using web applications, regardless of their planned future publishing be that printed or digital format. The Croatian Encyclopaedia and the Proleksis Encyclopaedia, two online encyclopaedias, are fully compiled and published in the digital form. The process of production of an online encyclopaedia differs from the production of its paper form, the new possibilities of content design, presentation, interconnection and usage leads to a paradigm shift. The switch to the digital editions enabled lexicographers to use the supporting ICT-based system to work more efficiently, to update content regularly, and to publish digital content faster. With that transition, "the very way in which encyclopaedias are produced has changed, at the same time as communication and use of encyclopaedic knowledge has become different, always avail-

\footnotetext{
${ }^{14}$ Regulation on the lexicographic work in the Miroslav Krleža Institute of Lexicography (in Croatian), 19 November 2013. The Law on the Miroslav Krleža Institute of Lexicography, by which the Regulation is governed, regulates that lexicographers are engaged both in lexicographic and encyclopaedic work. According to this, the authors use the term lexicographer equally in the context of lexicographic and encyclopaedic work.

${ }^{15}$ Even before 2009, the Institute had published several digital editions - in a co-publishing effort with the publishing house Masmedia, it has published The Lexicon of Economy on a CD-ROM (1995), a Croatia Tourist Guide on a CD-ROM (2000), and, with the co-publisher EURO-CAL, San Pedro, California, USA, a pocket device World-traveler - 15 language translator (1998).
} 
able and in constant competition with other sources"16 such as Wikipedia, the most commonly used encyclopaedia today. While encyclopaedias online strive to the total access to knowledge, allowing the exchange of ideas, they also protect cultural heritage and particularities, and constantly explore new possibilities for connecting (both existing and new) content. They assume a different organisation of information and interactivity in work. ${ }^{17}$ The properties and functionalities of the digital media does not question the encyclopaedic concept, consisting of encyclopaedic principles, ${ }^{18}$ but do question the profitability of printed editions. A redefinition of the role the lexicographers will play in the production and publishing of encyclopaedias in the digital form is needed. ${ }^{19}$ They will be required to become proficient with the ever-changing digital concepts and technologies as well as understandable of the digital processes and user expectations.

The Institute's plan for the future is to upgrade existing web applications while creating new ones that will enable lexicographic work and presentation of its results entirely in the digital environment. The upgrading of the process of lexicographic work in the digital environment should facilitate the work of lexicographers as well as accelerate the publishing of new encyclopaedic content online. The process of improvement of the lexicographic work will consequently improve the development of the Institute's repository of encyclopaedic knowledge.

\section{Repository of encyclopaedic knowledge}

The necessary preconditions for the establishment of the Institute's e-content, i.e. digital repository of encyclopaedic content, include digitisation of published editions, development of an institution-level repository of all digitised and digital encyclopaedic content and its adequate presentation online. Digitisation of the Institute's published editions, as well as the development of the repository, currently only of the digitised encyclopaedic content, was initiated in 2009. It is an ongoing project, with the purpose of digitising all archival editions and making them available to the users. In time, digitally-born editions will be included as well. Digitisation is nowadays the Institute's dominant means for making the printed editions globally accessible and reusable. The repository of

\footnotetext{
${ }^{16}$ Sundin, Olof; Haider, Jutta. The networked life of professional encyclopaedias: Quantification, tradition, and trustworthiness. // First Monday, 8 (2013) 6.

${ }^{17}$ Prelog, Nenad; Bebić, Domagoj. From Who and What to How and Why - The Future of Online Encyclopaedias. // INFuture2011: Information Sciences and e-Society / Billenness, C. et al. (ed.). Zagreb: Department of Information Sciences, Faculty of Humanities and Social Sciences, University of Zagreb, 2011, p. 301.

18 Jecić, Zdenko. Enciklopedički koncept u mrežnom okruženju. // Studia lexicographica, 7 (2013), 2 (13), p. 113.

${ }^{19}$ Starčević Stančić, Irina; Kraus, Cvijeta. Hrvatska enciklopedija - od tiskanoga do mrežnoga izdanja. // Studia lexicographica, 8 (2014) 1 (14), pp. 101-102.
} 
digitised archival editions thus contributes to the dissemination and preservation of encyclopaedic heritage and facilitates the lexicographic and encyclopaedic activities. This highlights the need that all remaining published encyclopaedic content should be digitised as soon as possible. Once in the digital form, it will also facilitate the development of new encyclopaedic products.

The Institute's future publishing policy will be oriented to a large extent towards the more significant presence of the digitised and digital contents on the web as well as towards the improvement of the organisation of the existing repository. The plan is to link all digitised and online editions, both current as well as the future ones, in the repository of encyclopaedic content which will be available to the global community free of charge. The development of the fully-blown institution-level repository will need careful planning and adaptation of the Institute's business processes.

Establishment of such a repository of encyclopaedic knowledge, as a form of a public knowledge, would enable the possibilities of linking to digital repositories of other scientific and cultural institutions in Croatia, as well as abroad. On the international level, the Institute's plan is to initiate the project of online linking of the European general encyclopaedias, focusing on those from small to medium language populations, through cooperation with similar European institutions. The scope of the project, apart from the connecting of the encyclopaedically organised knowledge in Europe, would be preservation of the multicultural aspect of the European countries.

Further, creation and organisation of open repositories of knowledge would help reinforce research e-infrastructure, and would also serve as the didactic tools, thus supporting the development of e-learning systems and curriculum links. ${ }^{20}$ To be precise, encyclopaedias form an important part of the infrastructure for learning in institutions like schools, libraries and universities and will, in all probability, continue to be indispensable in the future. ${ }^{21}$ Online encyclopaedic content will also help popularise the results of scientific research and develop recognisability of the Croatian national heritage.

\section{Digital communication with users}

The growth of ICT has changed the ways how institutions communicate with their users. They use the internet in order to find new information and create new social interactions - make new friends, keep existing ones, observe interactions of other people and sometime copy their friends' behaviour. According to boyd and Ellison (2008) "we define social network sites as web-based services that allow individuals to (1) construct a public or semi-public profile within a bounded system, (2) articulate a list of other users with whom they

\footnotetext{
${ }^{20}$ Strategy of education, science and technology (in Croatian), 17 October 2014.

${ }^{21}$ Sundin, Haider, 2013.
} 
share a connection, and (3) view and traverse their list of connections and those made by others within the system." ${ }^{22}$ Social networks play an important role for individuals. Okazaki and Taylor (2015) think that "social media at the same time represent a powerful personalization tool as they enable individuals to both produce and distribute content by their own participation." 23

\section{Social networks and encyclopaedia publishers}

Following the trend of increasing use of social networks it can be determined that various institutions are more and more involved with the social networks and by them attract a large number of users. Social networks are becoming a place where institutions can approach their users more easily and offer their content, exchange experiences, listen to their comments and use them to improve their products. Currently the most popular social networks are Facebook, Twitter, YouTube, LinkedIn, Instagram and Pinterest. Almost all encyclopaedia publishers have their own websites which are primary places for their content. This content is then used as a basis of interaction with the users via social networks.

Investigating the presence of encyclopaedia publishers on social networks, one can notice that Encyclopaedia Britannica updates its content frequently, the website is updated daily, publishes newsletters, develops mobile applications and in this way approaches end users and adapts to their ways of communication.

Swedish Nationalencyklopedin and Spanish Enciclopèdia Catalana are present on Facebook, Twitter, YouTube and Instagram. Italian Encyclopaedia of Science, Letters, and Arts (Treccani encyclopaedia) is present on Facebook, Twitter and YouTube. Encyclopaedia Universalis (in French, published by Encyclopaedia Britannica, Inc.) is present on Facebook and Twitter while Danish Den Store Danske and Croatian Croatian Encyclopaedia are present only on Facebook.

By following the trends of the previously mentioned encyclopaedia publishers, the Miroslav Krleža Institute of Lexicography has a nascent social media involvement. The website of the Institute is essential to the promotion and popularisation of the lexicographic and encyclopaedic activities ${ }^{24}$. Through it, the public is informed about current events and achievements related to the activities of the Institute and with its digital content. Further development of the Institute's website started in 2011, when a redesign of the previous web pages was

\footnotetext{
${ }^{22}$ boyd, danah m.; Ellison, Nicole B. Social Network Sites: Definition, History and Scholarship. // Journal of Computer-Mediated Communication. 13 (2008), 1; p. 211.

${ }^{23}$ Okazaki, Shintaro; Taylor, Charles R. Social media and international advertising: theoretical challenges and future directions. // International Marketing Review. 30 (2015), 1; p. 58.

${ }^{24}$ The Miroslav Krleža Institute of Lexicography, http://www.lzmk.hr (14.06.2015).
} 
made. Part of the Institute's website content has been translated into English and a Facebook account was opened ${ }^{25}$.

Having great content, knowing your audience and consistency ${ }^{26}$ are the three main components when discussing what it takes for an encyclopaedia publisher to successfully run a social media channel.

The Institute needs to produce a plan for its social media approach that is interesting for users. When publishing content via social media channels it is necessary to include more people and set up a team that is responsible for social networks. The team should create a publication cycle (daily, weekly and monthly), create a calendar of important dates in order to facilitate pace of publication, define responsibilities among editors (monthly and weekly assignments), answer questions posted by users through social networks, provide feedback to the editors, moderate online discussions, monitor posts and develop new social media content accordingly.

\section{Conclusion}

The publications of the Miroslav Krleža Institute of Lexicography, thanks to its tradition and reputation, have played a significant role in creation, maintenance and distribution of the public knowledge in Croatia. In the context of information and communication technologies and ever-increasing amount of available information, they offer scientifically verified and systematised foundation for the orientation in the context of global information. In the field of new technologies, the digitisation of published editions has been going on since 2009, as well as the establishment of the online repository of digitised encyclopaedic content. Moreover, some of the fundamental ongoing editions (e.g. general encyclopaedias) are edited and presented to the public as online editions, too. In the forthcoming years the activity of the Institute will be focused towards the establishment of the freely available online repository of encyclopaedic knowledge, which, in part, will be continuously updated. For that purpose, there is a need to upgrade the process of lexicographic work from the traditional, i.e. paper-based environment towards the digital environment. This would facilitate the work of lexicographers, as well as accelerate the process of publishing online encyclopaedic content. Furthermore, the interaction with users should also be adapted to the digital environment and facilitated through the active social media presence.

As an organised system of the production of encyclopaedic content, the Institute has the possibility of participating in systematising, linking and building of

\footnotetext{
${ }^{25}$ In December 2011 the Miroslav Krleža Institute of Lexicography's website was voted No 1 website in Croatia in the category "Government organizations, government institutions and public services" by the VIDI Web Top 100 Contest.

${ }^{26}$ King, David Lee. Managing Your Library's Social Media Channels. Chicago : ALA TechSource, 2015, p. 22.
} 
knowledge provided by various scientific, archival, documentation and information sources. By means of the possible future linking to the digital repositories of other scientific institutions, the development of the e-infrastructure of the Croatian educational and research area could be supported.

Finally, the development of the new ICT-based business model, entailing a system that would connect editing and publishing of the printed editions with the digital editions published online, is a complex and challenging task. Even more, one should also consider that the two processes, although having the same underlying lexicographic and encyclopaedic principles, are fundamentally different in their nature because of all the possibilities of platform portability, browsing, searching, text analysis, comparison, dynamic updating, interaction, long-term preservation of ever-changing digital media and formats etc. All those possibilities require professionals proficient with those concepts and understandable of the digital processes and user expectations. Nevertheless, there is no other way to go but to fine-tune lexicographic and encyclopaedic processes and practices to the digital realm, introduce the needed changes in the business processes and drive the Institute towards the concept of e-institution.

\section{References}

boyd, danah m.; Ellison, Nicole B. Social Network Sites: Definition, History and Scholarship. // Journal of Computer-Mediated Communication. 13 (2008), 1; pp. 210-230.

Digital Agenda for Europe - A Europe 2020 Initiative, http://ec.europa.eu/digital-agenda/en/ open-science (14.06.2015)

Ekonomski leksikon / ur. Z. Baletić. Zagreb, Leksikografski zavod Miroslav Krleža i Masmedia, 1995.

Jecić, Zdenko. Enciklopedički koncept u mrežnom okruženju. // Studia lexicographica, 7 (2013), 2 (13), pp. 99-115.

King, David Lee. Managing Your Library's Social Media Channels. Chicago : ALA TechSource, 2015

Mullan, Eileen. What is Digital Content?, EContent, 19 December 2011. http://www.econtent mag.com/Articles/Resources/Defining-EContent/What-is-Digital-Content-79501.htm (14.06.2015)

O’Brien, James A.; Marakas, George M. Management Information Systems. New York : McGraw-Hill, 2011.

Okazaki, Shintaro; Taylor, Charles R. Social media and international advertising: theoretical challenges and future directions. // International Marketing Review. 30 (2015), 1; pp. 56-71.

PC encyclopaedia, http://www.pcmag.com/encyclopedia/term/42225/e-content (14.06.2015)

Prelog, Nenad; Bebić, Domagoj. From Who and What to How and Why - The Future of Online Encyclopaedias. // INFuture2011: Information Sciences and e-Society / Billenness, C. et al. (ed.). Zagreb: Department of Information Sciences, Faculty of Humanities and Social Sciences, University of Zagreb, 2011, pp. 299-308.

Starčević Stančić, Irina; Kraus, Cvijeta. Hrvatska enciklopedija - od tiskanoga do mrežnoga izdanja. // Studia lexicographica, 8 (2014) 1 (14), pp. 99-116.

Statute of the Miroslav Krleža Institute of Lexicography, Official Gazette 66/2013.

Strategy of education, science and technology, 17 October 2014.

Strategy of the Miroslav Krleža Institute of Lexicography 2015-2020.

Sundin, Olof; Haider, Jutta. The networked life of professional encyclopaedias: Quantification, tradition, and trustworthiness. // First Monday, 8 (2013) 6. 
The Law on the Miroslav Krleža Institute of Lexicography, Official Gazette 96/2003, 190/2003.

What is Enterprise Content Management (ECM)?, Association for Information and Image Management (AIIM), http://www.aiim.org/What-is-ECM-Enterprise-Content-Management (14.06. 2015)

\section{Links}

Croatian Encyclopaedia, http://enciklopedija.hr Den Store Danske, http://www.denstoredanske.dk

Enciclopèdia Catalana, http://www.enciclopedia.cat

Enciclopedia Treccani, http://www.treccani.it

Encyclopaedia Universalis, http://www.universalis.fr

Nationalencyklopedin, http://www.ne.se

Portal of Knowledge, http://enciklopedija.lzmk.hr

Proleksis encyclopaedia, http://proleksis.lzmk.hr

Studia lexicographica, http:// www lzmk.hr/hr/leksikografska-djelatnost/studia-lexicographica

The Digitised Author Catalogue, http://katalog.lzmk.hr

The Miroslav Krleža Institute of Lexicography, http://www.lzmk.hr 